\title{
Pengaruh Pelatihan, Motivasi dan Lingkungan Kerja terhadap Kinerja Karyawan pada PT. Sumber Rukun Mandiri Mojokerto
}

\author{
Khasbulloh Huda \\ Universitas Mayjen Sungkono Mojokerto \\ Rachmad Sholeh \\ Universitas Mayjen Sungkono Mojokerto \\ hudakhasbulloh2@gmail.com
}

\begin{abstract}
Abstrak
Penelitian ini bertujuan untuk mengetahui Pengaruh Pelatihan Keja $\left(X_{1}\right)$, Motivasi Keja $\left(X_{2}\right)$, dan Lingkungan Kerja $\left(\mathrm{X}_{3}\right)$ terhadap Kinerja Karyawan $(\mathrm{Y})$. Serta untuk mengetahui variabel mana yang mempunyai pengaruh paling besar terhadap kinerja karyawanPT. Sumber Rukun Mandiri.Dari hasil analisa regresi didapat hasil variabel $\mathrm{X}$ yaitu Pelatihan Kerja, Motivasi Kerja dan Lingkungan Kerja mempunyai pengaruh terhadap kinerja karyawan secara simultan deangan nilaiF hitungsebesar208,097>dari $\mathrm{F}$ tabel2,04 yang berarti mempunyai pengaruh terhadap kinerja karyawan sebesar 0,897 atau 89,7\%. Sertavariabel Pelatihan Keja $\left(\mathrm{X}_{1}\right)$ secara parsial mempunyai pengaruh terhadap kinerja karyawan sebesar 0,431 atau 43,1\% dengan tingkat signifikan sebesar 0,000. Variabel Motivasi Keja $\left(\mathrm{X}_{2}\right)$ secara parsial juga mempunyai pengaruh terhadap kinerja karyawan sebesar 0,410 atau 41\%. Variabel LingkunganKerja $\left(\mathrm{X}_{3}\right)$ secara parsial mempunyai pengaruh terhadap kinerja karyawan sebesar 0,162 atau 16,2\%. Dan variabel pelatihan kerja merupakan variabel yang paling dominan pengaruhnya terhadap kinerja karyawan yang mempunyai niali pengaruh paling besar diantara variabel yang lain.
\end{abstract}

Kata kunci : Pelatihan Kerja, Motivasi Kerja, Lingkungan Kerja, dan Kinerja

\section{Pendahuluan}

Industri makanan merupakan industri yang paling banyak diminati dari beberapa pengusaha, dan merupakan sebuah industri yang paling prospektif diberbagai dunia tidak terkecuali di indonesia. Industri makanan adalah suatu faktor yang tidak akan hilang di makan waktu, itu disebabkan karena perilaku manusia yang menginginkan suatu barang tanpa harus melakukan suatu kegiatan untuk mendapatkan makanan.Karena tingginya tingkat kebutuhan makanan saji, industri ini merupakan yang paling menjanjikan bagi kalangan pengusaha.Sehingga semakin banyak bermunculan industri dalam bidang makanan atau yang bisa disebut catering servis. Industri ini sangat menarik terutama bagi kaum hawa. Dengan meningkatnya jumlah penduduk dari tahun ketahun menyebabkan tingkat kebutuhan pangan juga semakin meningkat pula. Peningkatan kebutuhan pangan tersebut mendatangkan peluangpeluang bisnis diindustri makanan. Industri makanan banyak diminati dikarenakan tingkat pengembalian modal yang relatif lebih cepat, hal ini terlihat dari semakin banyaknya bermunculan industri makanan baik dengan sekala kecil maupun skala besar. Selain itu, jika dilihat dari segi efesiensi dan biaya industri makanan banyak menghemat biaya investasi (Purwati Tj 1994.2). 


\section{Khasbulloh Huda,Rachmad Sholeh}

Pelatihan kerja menurut, (Meldona 2009:232) suatu proses untuk perubahan tingkahlaku karyawan dalam perusahaan dalam meningkatkan capaian tujuan perusahaan. Sedangkan menurut (Widodo 2015:82) pelatihan merupakan suatu aktivitas perorangan untuk meningkatkan kemampuan dalam hal keahlian, pengetahuan secara sistematis sehingga memiliki kemampuan dalam meingkatkan kinerja yang professional sesuai dengan bidangnya. Pelatihan merupakan proses pembelajaran yang sesuai dengan standar pekerjaan. Dengan adanya tuntutan kualitas dari pelanggan, maka perlu adanya pelatihan-pelatihan yang di berikan kepada kayawan agar berkerja sesuai dengan permintaan dan kebutuhan yang di perlukan oleh pasar dari industry makanan.

Menurut Mangkunegara (2010:61) Motivasi tumbuh berdasarkan sikap karyawan untuk menghadapi kondisi kerja dalam perusahaan. Motivasi merupakan suatu kondisi yang mendorong diri karyawan yang lebih terarah untuk mencapai tujuan perusahaan. Serta dorongan atau motivasi pada karyawan sangatlah diperlukan untuk meningkatkan kinerja sehingga tujuan perusahaan ini dapat tercapai (Hasibuan 2009:97). Pada industri makanan lingkungan kerja adalah salah satu hal yang utama, baik umtuk menjaga kualitas makanan maupun hubungan antar karyawan. Lingkungan kerja yang sangat sehat akan berdampak pada meningkatnya kinerja karyawan. Dari segi makanan juga di perlukan lingkungan kerja yang sangat sehat, baik dalam hal kebersihan lingkungan maupun kebersihan alat masak yang digunakan.

Menurut Menurut (Sunyoto 2015:38) lingkungan kerja merupakan bagian elemen yang sangat penting dalam menjalakan aktifitas pekerjaan pada suatu perusahaan.Sedangkan menurut menurut (Nuraini 2013:97) Lingkungan kerja merupakan komponen perusahaan yang mempunyai pengaruh kuat dalam membentuk prilaku karyawan dalam perusahaan. Adanya sarana dan prasarana kerja yang harus sesuai dengan karakter tugas maka kondisi kerja menjadi kondusif.

PT. Sumber Rukun Mandiri adalah sebuah industri makanan atau catering servis sebagai perusahaan menyediakan makanan sehari-hari pada siswa Sekolah Polisi Negara Mojokerto. Tingkat kebutuhan yang sangat tinggi untuk memberikan sajian pada hidangan serta keseimbngan gizi dan juga ketepatan waktu sangatlah di pertimbangkan dalam hal ini. Oleh karenanya PT. Sumber Rukun Mandiri selalu memberikan pelatihan-pelatian pada karyawananya baik di lingkup maupun diluar perusahaan. Agar bisa bersaing dengan perusahaan lainnya dalam bidang yang sama. Pelatiahn ini perlukan untuk meningkatkan kinerja baik dari sisi cara, gizi serta pada penyajian. Dengan adanya pelatihan, diharapkan sebagai pendorong serta motivasi pada karywan PT. Sumber Rukun Mandiri agar lebih baik dalam melakukan pekerjaan. Pada PT. Sumber Rukun Mandiri juga mempertimbangkan lingkungan kerja yang lebih nyaman dan bersih serta higenis untuk menjaga kualitas makanan serta kenyamanan lingkungan kerja agar karyawan menjalankan tugasnya dengan baik dan benar, serta mengurangi tingkat keluar masuknya karyawan yang disebabkan oleh lingkungan kerja.

Tujuan Penelitian penelitian ini adalah :

a. Mengetahui pengaruh Pelatihan, Motivasi, dan lingkungan kerja mempunyai pengaruh signifikan secara simultan terhadap kinerja karyawan

b. Untuk mengetahui Pelatihan, Motivasi, dan lingkungan kerja mempunyai pengaruh signifikan secara parial terhadap kinerja karyawan

c. Untuk mengetahui dari ketiga variabel manakah yang mempunyai pengaruh paling dominan terhadap kinerja karyawan 


\section{Khasbulloh Huda,Rachmad Sholeh}

Manfaat dalam penelitian ini diharapkan memberi informasi kepada PT. Sumber Rukun Mandiri dalam meningkatkat kinerja karyawan. Melalui peningkatan pelatihan, motivasi serta lingkungan kerja dalam hal peningkatan kinerja karyawan.

\section{Landasan Teori Pelatihan}

Pelatihan kerja merupakan sesuatu yang harus dilakukan oleh semua perusahaan, yang bertujuan untuk meningkatkan kemampuan, ketrampilan serta pengetahuan pada karyawan. Pelatiahan adalah suatu tindakan yang dilakukan oleh perusahaan agar lebih meningkatkan tentang pengetahuan, ketrampilan dan kemampuan karyawan supaya dapat lebih efektif dan efisien dalam menjalankan pekerjaan. (Hasibuan2009:66). Sedangkan menurut (Dessler 2010:280) pelatihan kerja proses peningkatan kerampilan yang dibutuhkan oleh karyawan dalam melakukan pekerjaannya. Bagi (Mangkunegara 2010: 51) mengutarakan jika Materi pelatihan serta pengembangan wajib disesuaikan dengan tujuan yang hendak dicapai, modul wajib diberikan secara sistematis serta bersumber pada tahapan-tahapan.

Merujuk sumber di atas bisa disimpulkan kalau pemilihan materi yang digunakan dalam pelatihan wajib mencermati dari kesesuaian pekerjaan, pembelajaran, keadaan pelatihan, syarat alokasi waktu pelatihan serta isi modul pelatihan haruslah diperbarui sehingga tujuan pelatihan bisa tercapai.

Menurut (Meldona 2009:248) Dalam melaksankana pelatihan ada beberapa faktor faktor yang berperan, yaitu :1). Biaya yang murah; 2). Sesuai dengan kebutuhan materi; 3). Prinsip-prinsip pembelajaran; 4). Ketepatan dan kesesuaian fasilitas; 5). Kesesuaian dengan kemampuan peserta pelatihan, dan 6). Kemampuan instrument pelatihan. Menurut (Mangkunegara 2009:44) tujuan pelatihan pada biasanya dalam rangka pembinaan terhadap tenaga kerja atau karyawan : 1) Tingkatkan karakter serta semangat dedikasi kepada organisasi serta perusahaan; 2) Tingkatkan ilmu pengetahuan, keahlian dan keterampilan baik dalam melakukan tugasnya ataupun kepemimpinan; 3) Melatih serta meningkatkan mekanisme kerja.

\section{Motivasi}

Motivasi kerja adalah sesuatu yang meningkatkan dan mendorong semangat bekerja. Adapun faktor yang dapat rneningkatkan motivasi kerja, yaitu atasan, kolega, sarana fisik, kebijaksanaan, peraturan, imbalan jasa uang dan non-uang, jenis pekerjaan, dan tantangan. Motivasi individu untuk bekerja dipengaruhi pula oleh kepentingan pribadi dan kebutuhannya masing-masing. Menurut (Samsudin 2006:281) mengatakan bahwa : Motivasi adalah cara untuk mempengaruhi atau mendorong dari luar terhadap seseorang atau kelompok kerja agar mereka mau melaksanakan suatu pekerjaan yang telah diberikan. Motivasi dari dalam diri karyawan bisa berasal dari kebutuhan akan uang, penghargaan, kekuasaan, serta pengakuan. Motivasi dari luar bisa berasal dari keluarga, sahabat kerja, ataupun atasan. Pada garis besarnya motivasi yang diberikan dapat dipecah jadi 2 (Heidjrachman serta Husnan 2002), ialah motivasi positif serta motivasi negatif. Motivasi positif merupakan proses pengaruhi orang dengan memberikan kemungkinan memperoleh hadiah sedangkan motivasi negatif merupakan proses pengaruhi seorang lewat kekuatan ketakutan semacam kehabisan pengakuan, duit ataupun 


\section{Khasbulloh Huda,Rachmad Sholeh}

jabatan. Bagi (Nawawi 2000), terdapat 2 wujud motivasi ialah motivasi intrinsik serta motivasi ekstrinsik. Motivasi intrinsik merupakan pendorong kerja yang bersumber dari dalam diri pekerja berbentuk pemahaman tentang arti pekerjaan yang dilaksanakan. Motivasi ekstrinsik merupakan pendorong kerja yang bersumber dari luar diri pekerja berbentuk sesuatu keadaan yang mewajibkan melakukan pekerjaan secara optimal.

Dikalangan para teoritikus dan praktisi manajemen diatas diketahui bahwa masalah motivasi bukanlah suatu hal yang menjadi masalah mudah, baik memahaminya ataupun menerapkannya. Akan tetapi yang jelas ialah bahwa dengan motivasi yang tepat maka para karyawan akan terdorong untuk berbuat semaksimal mungkin dalam melaksanakan tugasnya, karena menyakini bahwa dengan keberhasilan serta mencapai tujuan dan berbagai sasarannya, kepentingan-kepentingan pribadi para anggota organisasi tersebut akan terpelihara pula. Di dalam perusahaan yang berorientasi pada keuntungan, motivasi merupakan hal yang terpenting bagi pimpinan, pimpinan berusaha memahami perilaku semua karyawan agar dapat mempengaruhi mereka sesuai dengan yang diinginkan perusahaan. Maka salah satu tugas manajer adalah memberikan motivasi (dorongan) kepada para bawahannya supaya bisa menjalankan tugas sesuai dengan pengarahan yang diberikan, dan karyawan dapat saling bekerjasama sehingga mampu mencapai hasil maksimal.

\section{Lingkungan Kerja}

Lingkungan kerja merupakan suatu yang ada disekitar para pekerja yang dapat mempengaruhi dalam menjalankan tugas atau pekerjaan yang di bebankan. Lingkungan kerja yang baik adalah lingkungan dengan kondisi dimana para karyawan atau pekerja dapat melaksanakan tugas pekerjaan dengan maksimal, sehat, aman, serta membawa kenyamanan. Kesesuaian lingkungan kerja dapat dilihat pada karyawan yang lebih lama dalam lingkungan kerja. Lingkungan kerja merupakan segala sesuatu yang ada pada lingkungan karyawan pada saat bekerja baik dalam bentuk fisik maupun non fisik, langsung ataupun tidak langsung yang dapat memperngaruhi karyawan saat bekerja (Sedarmayanti2001:12). Sedangkan menurut (Simanjuntak 2003: 39) Menyatakan lingkungan kerja dapat diartikan sebagai keseluruhan alat perkakas yang dihadapi, lingkungan sekitarnya dimana seorang bekerja, metode kerjanya, sebagai pengaruh kerjanya baik sebagai perorangan maupun sebagai kelompok.

Aspek lain yang pengaruhi kinerja serta kepuasan kerja pegawai dalam melakukan tugas merupakan area kerja ialah seluruh suatu yang terdapat di dekat pekerja, yang bisa pengaruhi dirinya dalam melaksanakan tugas (Nitisemito 1996). Aspek area kerja dapat berbentuk keadaan raga kantor yang meliputi penerangan, temperatur hawa, dll yang sanggup tingkatkan atmosfer kondusif serta semangat kerja dan mempengaruhi terhadap kinerja karyawan (Sedarmayanti 2001). Bagi (Mangkunegara 2006) area kerja meliputi penjelasan jabatan yang jelas, autoritas yang mencukupi, sasaran kerja yang menantang, pola komunikasi, ikatan kerja yang harmonis, hawa kerja yang dinamis, kesempatan karir, serta sarana kerja yang mencukupi.

\section{Kinerja}

Kinerja karyawan adalah tingkat pencapaian hasil kerja karyawan dalam perusahaan. Konsep kinerja merupakan singkatan dari kinetika energi kerja yang padanannya dalam bahasa inggris adalah performance. Dalam interaksi sehari-hari, antara pimpinan dan karyawan, berbagai asumsi dan harapan pasti banyak bermunculan. Ketika atasan dan bawahan 


\section{Khasbulloh Huda,Rachmad Sholeh}

membentuk serangkaian asumsi dan harapan mereka masing-masing yang sering kali agak berbeda, perbedaan-perbedaan ini yang akhirnya berpengaruh pada tingkat kinerja pegawai.

Menurut (Mangkunegara 2009: 67) penafsiran kinerja merupakan hasil kerja secara mutu serta kuantitas yang dicapai oleh seorang pegawai dalam melakukan tugasnya sesuai dengan tanggungjawab yang diberikan kepadanya. Sedangkan menurut Menurut (Wibowo 2010:4) Kinerja adalah penerapan dari rencana yang telah disusun tersebut. Penerapan kinerja dilakukan oleh sumber daya manusia yang mempunyai kemampuan, kompetensi, motivasi, dan kepentingan. Bagaimana organisasi seharusnya menghargai dan memperlakukan sumber daya manusianya yang memengaruhi sikap dan perilakunya dalam menjalankan kinerja. Sementara menurut (Simanjuntak 2010:1), kinerja adalah tingkat pencapaian hasil atas melaksanakan tugas tertentu.

\section{Kerangka Konseptual dan Hipotesis}

Kerangka konseptual pada penelitian ini dapa dilihat sebagai berikut :

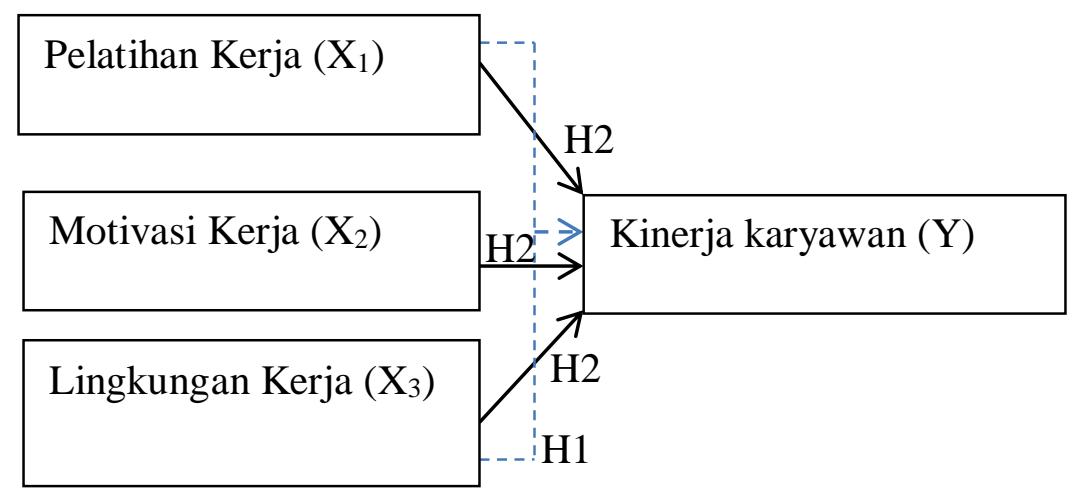

Gambar.1.Kerangka Konseptual

Keterangan :

$---\rightarrow \quad=$ Simultan

$\longrightarrow \quad=$ Partial

\section{Hipotesis}

Dilihat dari kerangka konseptual diatas dapat disimpukan hipotesis sebagai berikut :

1. Pelatiahan, Motivasi dan lingkungan kerja mempunyai pengaruh signifikan secara simultan terhadap kinerja karyawan

2. Pelatiahan, Motivasi dan lingkungan kerja mempunyai pengaruh signifikan secara partial terhadap kinerja karyawan

\section{Metode Penelitian}

Penelitian ini merupakan penelitian eksperimen dengan bentuk dalam data kuantitatif, menurut (Sugiyono 2010:35). Penelitian eksperimen merupakan penelitian yang sistimatis, logis, dan teliti didalam melakukan kontrol terhadap kondisi. Dalam melakukan eksperimen, peneliti memanipulasikan atau stimulan, treatmen atau kondidi-kondisi eksperimental, kemudian mengobservasi pengaruh yang diakibatkan oleh adanya perlakuan.Denga jumlah 


\section{Khasbulloh Huda,Rachmad Sholeh}

sampel sebesar 60 responden. Sampel yang digunakan pada penelitain ini seluruh karyawan PT. Sumber Rukun Mandiri yang berjumlah 60 orang karyawan. Menurut (Arikunto2002:100), apabila subyek kurang dari 100, maka lebih baik diambil seluruhnya, sehingga, penelitiannya merupakan penelitian populasi. Model analisis data yang digunakan untuk menjawab hipotesis dengan menggunakan regresi linier berganda menggunakan software SPSS (Statistical Package for Social Science) dengan formulasi persamaan sebagai berikut

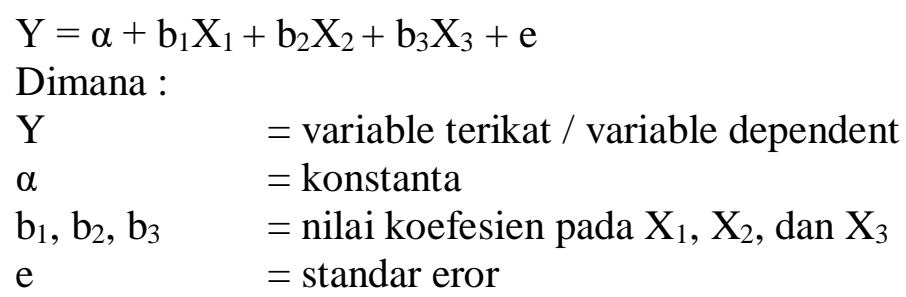

Menurut (Sanusi 2011:115); Teknik analisis dalam penelitian ini menggunakan 1) Analisis Deskriptif, analisis digunakan untuk menganalisis data dengan membuat deskripsif atau menggambarkan data yang terkumpul tanpa bermaksud untuk membuat kesimpulan yang berlaku umum; 2) uji simultan (uji f), yaitu digunakan untuk menguji pengeruh secara bersama dari variabel bebas terhadap variabel terikat; 3 ) uji parsial (uji t), yaitu untuk menguji pengaruh variabel bebas terhadap variabel terikat secara sendiri-sendiri; 4) analisis regresi linier berganda, yaitu untuk mengetahui penggaruh variabel pelatihan, variabel motivasi, dan variabel lingkungan kerja terhadap variabel kinerja karyawan. Serta juga digunakan untuk menguji kebenaran hipotesis menurut (Sanusi 2011:134).

\section{Hasil dan Pembahasan}

\section{Uji Validitas}

(Sugiyono2007:121) uji validitas di gunakan untuk mengukur sah atau valid tidaknya suatu kuesioner. Suatu kuesioner dikatakan valid jika pertanyaan pada kuesioner mampu untuk mengungkapkan sesuatu yang akan di ukur oleh kuesioner tersebut (Anwar

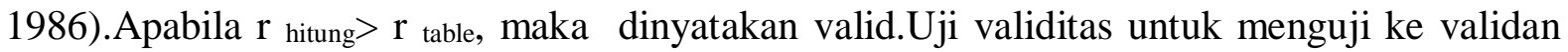
suatu konstruk dimana nilai dikatakan valid apabila nilai $r_{h i t u n g}>r_{\text {tabel }}$ dengan nilai $r_{\text {tabel }}$ sebesar 2,663 .

Tabel 1.Hasil Uji Validitas pada Variabel Pelatihan $\left(\mathrm{X}_{1}\right)$

\begin{tabular}{|c|c|c|c|}
\hline Indikator & Hasil & $\mathrm{r}$ - Tabel & Keterangan \\
\hline $\mathrm{X} 1.1$ &, 896 & 2,663 & Valid \\
$\mathrm{X} 1.2$ &, 941 & 2,663 & Valid \\
$\mathrm{X} 1.3$ &, 937 & 2,663 & Valid \\
\hline
\end{tabular}

Sumber : Data diolah

Dari data diatas diketahui bahwa semua konstruk pada variabel pelatihan mempunyai nilai $r_{\text {hitung }}$ lebih besar dari $r_{\text {tabel }}$ sehingga dapat diartika semua kontruk dinyatakan valid. 
INOBIS: Jurnal Inovasi Bisnis dan Manajemen Indonesia

Volume 02, Nomor 03, Bulan Jun 2019

Khasbulloh Huda,Rachmad Sholeh

Tabel 2.Hasil Uji Validitas pada Variabel Motivasi $\left(\mathrm{X}_{2}\right)$

\begin{tabular}{|c|c|c|c|}
\hline Indikator & Hasil & $\mathrm{r}$ - Tabel & Keterangan \\
\hline X2.1 &, 743 & 2,663 & Valid \\
X2.2 &, 831 & 2,663 & Valid \\
X2.3 &, 471 & 2,663 & Valid \\
\hline
\end{tabular}

Sumber : Data diolah

Dari data diatas diketahui bahwa semua konstruk pada variabel motivasi mempunyai nilai $r_{\text {hitung }}$ lebih besar dari $r_{\text {tabel }}$ sehingga dapat diartika semua kontruk dinyatakan valid.

Tabel 3.Hasil Uji Validitas pada Variabel Lingkungan Kerja $\left(\mathrm{X}_{3}\right)$

\begin{tabular}{|c|c|c|c|}
\hline Indikator & Hasil & $\mathrm{r}$ - Tabel & Keterangan \\
\hline X3.1 &, 800 & 2,663 & Valid \\
X3.2 &, 950 & 2,663 & Valid \\
X3.3 &, 831 & 2,663 & Valid \\
\hline
\end{tabular}

Sumber : Data diolah

Dari data diatas diketahui bahwa semua konstruk pada variabel lingkungan kerja mempunyai nilai $r_{\text {hitung }}$ lebih besar dari $r_{\text {tabel }}$ sehingga dapat diartika semua kontruk dinyatakan valid.

Tabel 4.Hasil Uji Validitas pada Variabel Lingkungan Kerja $\left(\mathrm{X}_{3}\right)$

\begin{tabular}{|c|c|c|c|}
\hline Indikator & Hasil & $\mathrm{r}$ - Tabel & Keterangan \\
\hline Y1.1 &, 950 & 2,663 & Valid \\
Y1.2 &, 813 & 2,663 & Valid \\
Y1.3 &, 638 & 2,663 & Valid \\
\hline
\end{tabular}

Sumber : Data diolah

Dari data diatas diketahui bahwa semua konstruk pada variabel kinerja karyawan mempunyai nilai $r_{h i t u n g}$ lebih besar dari $r_{\text {tabel }}$ sehingga dapat diartika semua kontruk dinyatakan valid.

\section{Uji Reliabelitas}

Uji reliabilitas atau kehandalan instrunment menunjukkan sejauh mana pengukuran dapat memberikan hasil yang sama jika dilakukan pengukuran kembali pada subyek penelitian yang sama. Menurut (Ghozali 2007:41), jika nilai Cronbach's Alpha > 0,60 maka dikatakan 


\section{Khasbulloh Huda,Rachmad Sholeh}

reliabel.Uji realibilitas digunakan untuk memastikan konstruk penelitian yang dipergunakan untuk pengumpulan data reliabel atau tidak (Anwar 1986). Jika nilai konstruk dinyatakan reliabel dilihat dari nilai Cronbach's Alpha lebih besar dari 0,6 atau 6\%.

Tabel 5. Hasil Uji Reliabelitas Pada Variabel Pelatihan, Motivasi dan Lingkungan Kerja pada Variabel Kinerja Karyawan

\begin{tabular}{|l|c|c|c|}
\hline \multicolumn{1}{|c|}{ Variabel } & Hasil & $\begin{array}{c}\text { Cronbach's } \\
\text { Alpha }\end{array}$ & Keterangan \\
\hline Pelatihan Kerja &, 957 & 0,6 & Reliabel \\
Motivasi Kerja &, 956 & 0,6 & Reliabel \\
Lingkungan Kerja &, 956 & 0,6 & Reliabel \\
\hline
\end{tabular}

Sumber : Data diolah

Berdasarkan dari hasil diatas dapat diketahui nilai pada variabel pelatihann sebesar 0,957, variabel motivasi sebesar 0,956 dan variabel lingkungan kerja sebesar 0,956. Bahwa semua konstruk dinyatakan reliabel dengan nilai Cronbach's Alpha lebih besar dari 0,6 atau $6 \%$.

\section{Uji f $(f$-test $)$}

Uji f digunakan untuk melihat pengaruh antara variabel independent terhadap variabel dependent secara simultan., yang mendasari nilai pengaruh yaitu dilihat dari hasil $\mathrm{t}$-hitungyang harus lebih besar dari t-tabel. Dan nilai signifikan $<\alpha$, maka secara silmultan variabel pelatihan, motivasi dan lingkungan kerja mempunyai pengaruh pada varibel kinerja karyawan.

Tabel 6. Hasil Uji f (f-test)

\begin{tabular}{|c|c|c|c|c|c|c|}
\hline \multicolumn{2}{|c|}{ Model } & $\begin{array}{l}\text { Sum of } \\
\text { Squares }\end{array}$ & df & $\begin{array}{l}\text { Mean } \\
\text { Square }\end{array}$ & $\mathrm{F}$ & Sig. \\
\hline \multirow{3}{*}{$x$} & Regression & 164,111 & 3 & 54,704 & 208,097 &, 000 \\
\hline & Residual & 17,876 & 68 & ,263 & & \\
\hline & Total & 181,986 & 71 & & & \\
\hline
\end{tabular}

Sumber : Data diolah, 2020

Dari hasil diatas diketahui nilai $\mathrm{f}$ hitung sebesar 208,097 dan nilai signifikan sebesar 0,000, kama dapat sisimpulkan bahwa variabel pelatihan, motivasi dan lingkungan kerja mempenyai pengaruh dan signifikan secara simultan terhadap variabel kinerja karyawan. Hal itu dikarenakan $\mathrm{f}_{\text {hitung }}>\mathrm{f}_{\text {tabel }}$, dan nilai signifikan dibawah 0,05 , dalam hal ini maka hipotisis 1 (H1) diterima.

\section{Uji t (t-test)}

Uji T (t-tes) merupakan uji pengaruh secara partial variabel independen terhapad variabel dependen, dasar nilai pengaruh dilihat dari perbandingan nilai $t_{\text {hitung }}>t$ tabel serta niali signifikan $<$ dari $\alpha$. 
INOBIS: Jurnal Inovasi Bisnis dan Manajemen Indonesia

Volume 02, Nomor 03, Bulan Jun 2019

Khasbulloh Huda,Rachmad Sholeh

Tabel 7. Hasil uji t (t-test)

\begin{tabular}{|l|l|l|l|}
\hline Variabel & $\beta$ & thitung & $\begin{array}{l}\text { Tingkat } \\
\text { Sig }\end{array}$ \\
\hline Pelatihan &, 431 & 4,382 &, 000 \\
\hline Motivasi &, 410 & 5,416 &, 000 \\
\hline Lingkungan Kerja &, 262 & 1,744 &, 013 \\
\hline
\end{tabular}

Sumber : Data diolah

Dari tabel diatas diketahui bahwa Variabel Pelatihan mempunyai pengaruh dan signifikan terhadap variabel kinerja karyawan secara parsial. Hal itu dikarenakan nilai t hitung sebesar 4,382 > dari nilai t tabel sebesar 1, 670, Dan nilai signifikan < dari 0,05 serta nilai koefesien sebesar 0,431, maka hipotesis $2(\mathrm{H} 2)$ diterima. Yang dapt diartikan jika variabel pelatihan dinaikan satu satuan maka nilai kinerja naik sebesar 0,431,. Dalam hal ini senada dengan penelitian milik (Lubis 2008) yang menerangkan bawa pelatihan mempunyai pengaruh terhadap kinerja karyawan. Dengan adanya kesesuaian pelatihan yang di lakukan oleh perusahaan melalui materi yang diberikan dan metode pelatihan yang tepat serta sasaran yang terukur, diharapkan pelatihan yang dilakukan dapat meningkatkan kinerja karyawan. Dan dilihat dari tujuan yang diharapkan dengan adanya pelatihan, Maka untuk menaikan kinerja karyawan selayaknya PT. Sumber Rukun Mandiri memperhatikan dan lebih meningkatkan lagi pelatihan-pelatihan untuk karyawannya sehingga kinerja karyawan juga akan meningkat. Hal itu disebabkan dengan adanya pelatihan akan berdampak pada penambahan pengetahuan, skill, dan kemampuan karyawan PT. Sumber Rukun Mandiri.

Pada Variabel Motivasi diketahui mempunyai pengeruh dan signifikan terhadap kinerja karyawan secara parsial. Hal ini disebabkan karena nilai t hitung sebesar 5,416 $>$ dari t tabel sebesar 1,670, dan nilai signifikan sebesar $0,000<0,05$, dengan nilai koefesien sebesar 0,410 maka hipotesis $2(\mathrm{H} 2)$ diterima. Dapat diartikan jika variabel motivasi dinaikkan satu satuan maka variabel kinerja karyawan naik sebesar 0,410.Hal ini sejalan dengan hasil penelitian milik (Anas 2010), yang mengatakan bahwa variabel motivasi mempunyai pengaru dan signifikan terhadap kinerja karyawan.Motivasi karyawaan sangat di perlukan agar kinerja karyawan dapat meningkat. Motivasi kerja akan tibul jika karyawan merasa tercukupi kebutuhan fisiologinya dalam bentuk memperoleh penghasilan yang cukup, serta dapat memenuhi kebutuah hidup, dan penghargaan yang diberikan kepada karyawan jika berprestasi. Dalam hal ini untuk menaikan kinerja karyawan maka PT. Sumber Rukun Mandiri senantiasa melakukan motivasi kerja terhadap karyawannya agar karyawan bisa lebih meningkatkan kinerjanya dengan memberikan upah yang sesuai, memberikan penghargaan pada karyawan yang berprestasi serta memberi rasa aman kepada karyawan.

Pada variabel Lingkungan Kerja juga diketahui mempunyai pengaruh dan signifikan terhadap variabel kinerja karyawan secara parsial. Hal ini disebabkan hasil dari penelitian nilai t hitung sebesar 1,744 > dari nilai t tabel sebesar 1,670, dan nilai signifikan sebesar 0,013 yang $<$ dari 0,05, serta nilai koefesien sebesar 0,262 maka hipotesis $2(\mathrm{H} 2)$ diterima. Yang dapat diartikan jika variabel lingkungan kerja dinaikkan satu satuan maka variabel kinerja karyawan juga naik sebesar 0,262. Hasil penelitian ini sejalan dengan penelitian milik (Hardiyana, dkk2011) yang mengatakan bahwa variabel lingkungan kerja mempunyai pengaruh dan 


\section{Khasbulloh Huda,Rachmad Sholeh}

signifikan terhadap kinerja karyawan. Lingkungan kerja yang sesuai akan meningkatkan kinerja karyawan, dengan penerangan yang cukup, lingkungan yang bersih dan peralatan yang memadai membuat kinerja karyawan akan meningkat. Maka dari itu untuk menunjang lingkungan kerja yang sesuai maka PT. Sumber Rukun Mandiriharus memperhatikan penerangan yang ada dalam tempat kerja, serta selalu menjaga kebersihan dan menyediakan peralatan - peralatan yang dibutuhkan dalam menyelesaikan pekerjaan agar hasil dari pekerjaan dapat dengan maksimal serta akan meningkatkan kinerja karyawan. Dengan lingkungan kerja yang sesuai secara otomatis hasil kerja karyawan akan meningkat.

Hasil penelitian ini juga mengetahui variabel mana yang mempuyai pengaruh paling dominan terhadap kinerja karyawan pada PT. Sumber Rukun Mandiri. Adapun variabel yang mempunyai pengaruh paling dominan yaitu variabel pelatihan kerja, hal ini disebabkan karena nilai pengaruh variabel tersebut paling besar diantara variabel lain sebesar 0,431, yang lebih besar dari nilai pengaruh variabel motivasi sebesar 0,410 dan nilai pengaruh variabel lingkungan kerja yang mempunyai nilai sebesar 0,262 .

\section{Uji Determinasi}

Uji determinasi digunakan untuk melihat besaran pengaruh variabel pelatihan, motivasi dan lingkungan kerja terhadap variabel kinerja karyawan secara simultan. Dari hasil penelitian ini dapat diketahui hasil uji determinasi pada tabel sebagai berikut :

Tabel 8. Hasil Uji Koefisien Determinasi

\begin{tabular}{|l|r|r|r|c|}
\hline Model & \multicolumn{1}{|c|}{$\mathrm{R}$} & $\begin{array}{c}\mathrm{R} \\
\text { Square }\end{array}$ & $\begin{array}{c}\text { Adjusted } \\
\text { R Square }\end{array}$ & $\begin{array}{c}\text { Std. Error of the } \\
\text { Estimate }\end{array}$ \\
\hline 1 &, $950^{\mathrm{a}}$ &, 902 &, 897 &, 51271 \\
\hline
\end{tabular}

Sumber : Data diolah, 2020

Dari tabel model summary diketahui bahwa variabel independent mempunyai pengaruh terhadap variabel dependent secara simultan sebesar 0,897 atau $89,7 \%$ sisanya dipengauhi variabel lain yang tidak diteliti.

\section{Analisis Regresi Linier Berganda}

Analisis regresi linier berganda digunakan untuk mengetahui pengaruh variable independent terhadap variable dependent secara parsial. Pada hasil statistik dari analisis linier berganda mengenai pengaruh variabel pelatihan, motivasi dan lingkungan kerja terhadap kinerja kaeyawan PT. Sumber Makmur sebagai berikut : 
INOBIS: Jurnal Inovasi Bisnis dan Manajemen Indonesia

Volume 02, Nomor 03, Bulan Jun 2019

Khasbulloh Huda,Rachmad Sholeh

Tabel 9.Hasil Analisis Regresi Linier Berganda

\begin{tabular}{|l|l|l|l|}
\hline Variabel & Koefesien Regresi & $\mathrm{t}$ hitung & Sig \\
\hline Pelatihan &, 431 & 4,382 &, 000 \\
\hline Motivasi &, 410 & 5,416 &, 000 \\
\hline Lingkungan Kerja &, 262 & 1,744 &, 013 \\
\hline Constanta $=0,734$ Std. Error of the Estimate =0,512 \\
\hline
\end{tabular}

Sumber : Data diolah

Berdasarkan dari tabel diatas, hasil regresi linier berganda dapat diformulasikan suatu persamaan sebagai berikut :

$$
Y=0,734+0,431 X_{1}+0,410 X_{2}+0,262 X_{3}+0,512
$$

Berikut ini adalah interprestasi dari hasil regresi linier berganda yang terdapat pada tabel di atas sebagai berikut :

$\mathrm{Y}=$ merupakan variabel terikat yang nilainya akan di prediksikan untuk variabel bebas. Dimana variabel terikat dalam penelitian ini adalah kinerja karyawan.

Konstanta $(\alpha)=0,734$ yaitu estimasi kinerja karyawan yang terdiri dari variabel pelatihan $\left(X_{1}\right)$, variabel motivasi $\left(\mathrm{X}_{2}\right)$, dan variabel lingkungan kerja $\left(\mathrm{X}_{3}\right)$ mempunyai nilai sama dengan nol.

Koefisien $\mathrm{X}_{1}\left(\mathrm{~b}_{1}\right)=0,431$ menunjukkan bahwa variabel pelatihan mempunyai pengaruh positif terhadap kinerja karyawan. Diartikan jika variabel pelatihan di tingkatkan satu satuan maka kinerja karyawan pada PT. Sumber Rukun Mandiri akan meningkat sebesar 0,431 atau 43,1\%.

Koefisien $\mathrm{X}_{2}\left(\mathrm{~b}_{2}\right)=0,410$ menunjukkan bahwa variabel motivasi mempunyai pengaruh positif terhadap kinerja karyawan. Diartikan jika variabel pelatihan di tingkatkan satu satuan maka kinerja karyawan pada PT. Sumber Rukun Mandiriakan meningkat sebesar 0,410 atau 41\%.

Koefisien $\mathrm{X}_{3}\left(\mathrm{~b}_{3}\right)=0,262$ menunjukkan bahwa variabel pelatihan mempunyai pengaruh positif terhadap kinerja karyawan. Diartikan jika variabel pelatihan di tingkatkan satu satuan maka kinerja karyawan pada PT. Sumber Rukun Mandiri akan meningkat sebesar 0,262 atau 26,2\%.

\section{Kesimpulan}

Berdasarkan hasil analisis data yang telah dilakukan terhadap seluruh data. Yang diperoleh sebagai berikut:

a. Secara simultan variabel pelatihan kerja, motivasi kerja dan lingkungan kerja mempunya pengaruh dan singnifikan terhadap kinerja karyawan pada PT. Sumber Rukun Mandiri. Hal ini dibuktikan dengan hasil penelitian pada uji f dengan nilai $\mathrm{f}$ hitung sebesar 208,097 dan nilai signifikan 0,000. Maka untuk meningkatkan kinerja karyawan pada PT. Sumber Rukun Mandiri harus melakukan pelatihan yang terstruktur dan berjangka, serta memberikan motivasi berupa penghargaan dan pemberian gaji yang sesuai, dan menjaga lingkungan kerja yang kondusif, baik mengenai penerangan, kebersihan dan peralatan yang digunakan. 
b. Secara parsial variabel pelatihan kerja, motivasi kerja dan lingkungan kerja mempunya pengaruh dan singnifikan terhadap kinerja karyawan pada PT. Sumber Rukun Mandiri. Hal ini dibuktikan pada nilai t hitung pada setia variabel lebih besar dari t tabel, dan nilai signifikan lebih kecil dari 0,05. Untuk meningkatkan kinerja karyawan PT. Sumber Rukun Mandiri perlu ditingkatkan lagi pelatihan pada karyawan sehingga meningkatnya pengetahuan, skill dan kemampuan serta meningkatkan motivasi melalui penghargaan dan pendapatan yang sesuai dan meningkatkan lingkungan kerja yang lebih kondusif.

c. Variabel pelatiahan kerja merupakan variabel yag paling dominan pengaruhnya terhadap kinerja karyawan PT. Sumber Rukun Mandiri dengan nilai yang paling besar pengaruhnya dibandingkan dengan variabel lainnya. Maka pelatihan merupakan hal yang terpenting demi meningkatkan kinerja karyawan pada PT. Sumber Rukun Mandiri.

\section{Daftar Pustaka}

Arikunto, Suharsimi. 2002, Penelitian Suatu Pendekatan Proposal. Jakarta. PT Rineka Cipta

Arikunto, Suharsimi. 2006, Prosedur Penelitian, Cetakan Ketigabelas, Jakarta. PT Rineka Cipta

Azwar, Saifudin, 1986. Validitas dan Rehabilitas. Cetakan pertama. Yogyakarta: Liberty.

Dessler, Gary. 2010. ManajemenSumber Daya Manusia. Edisi Kesepuluh. Jakarta Barat. PT Indeks

Ghozali, Imam. 2007. Aplikasi Analisis Multivariate dengan Program SPSS, Semarang: BP Undip Semarang

HardiyanaAan, Farina Helwiyan (2011), Pengaruh Kepemimpinan, Motivaasi dan Lingkungan Kerja Terhadap Kinerja Pegawai Badan Kepegawaian Pendidikan dan Pelatihan Kabupate Bandung, Jurnal Ekonomi, Bisnis \& Entrepreneurship Vol. 5, No. 2, Oktober 2011, 86-96 ISSN 2443-0633.

Hariawati, Erlina. 2009. Pengaruh Pelatihan kerja terhadap Peningkatan Prestasi Kerja Karyawan PT. Mandom Indonesia Tbk. Jurnal Ilmiah Abdi Ilmu. Vol. 2 No.1, hal. 120132.

Hasibuan: Malayu, 2009, Sumber Daya Manusia, Cet. Ke 13 Jakarta: salemba Empat.

Heidjrachman, R. dan Husnan, S. 2002. Manajemen Personalia. Edisi Keempat. Yogyakarta: BPFE

Husein Umar. 2005. Evaluasi Kinerja Perusahaan. Jakarta : Gramedia Pustaka Utama

Lubis, Khairul. 2008. Pengaruh Pelatihan dan Motivasi Kerja terhadap Kinerja Karyawan PT Perkebunan Nusantara IV (Persero) Medan. Tesis. Medan: Universitas Sumatera Utara.

Mangkunegara, A.P. 2006. Evaluasi Kinerja SDM. Bandung: Penerbit Refika Aditama

Mangkunegara,A.P. 2010. Manajemen Sumber daya Manusia perusahaan. Bandung: PT Remaja Rosdakarya.

Martoyo, Susilo. 2000. Manajemen Sumber Daya Manusia Edisi 4, Yogyakarta: BPFE Yogyakarta

Meldona, 2009, Manajemen Sumber Daya Manusia, Cetakan I. Malang:UIN-Malang.

Anas, Muhammad. 2010. Pengaruh Motivasi terhadap Kinerja Pegawai pada Kantor Balai Perbenihan Tanaman Hutan Sulawesi. Jurnal Motivasi terhadap kinerja. Universitas Sawerigading Makassar

Nawawi, Hadari. 2000. Manajemen Sumber Daya Manusia. Yogyakarta: Gajah Mada University Press. 
Notoatmodjo, Soekidjo. 2009. Pengembangan Sumber Daya Manusia, Jakarta: PT. Rineka Cipta

Nitisemito, A.S. 1996. Manajemen Sumber Daya Manusia. Cetakan Sembilan. Edisi Ketiga. Jakarta: Ghalia Indonesia.

Nuraini, T. 2013. Manajemen Sumber Daya Manusia, Yayasan Aini Syam: Pekanbaru.

Purwati Tj, dkk. 1994. Manajemen Katering. Fakultas Pendidikan dan Teknologi Kejuruan, Institut Keguruan dan Ilmu Pendidikan: Yogyakarta.

Robbins, S.P., 2006, Manajemen Sumber Daya Manusia, PT. Salemba Empat. Jakarta

Samsudin, Sadili; Wijaya, E.2006, Manajemen Sumber Daya Manusia, Cet.Ke-1. Bandung: Pusaka Setia.

Sanusi, Anwar. 2011. Metodologi Penelitian Bisnis. Edisi Ketiga. Jakarta. Salemba Empat.

Simanjuntak, Payaman J. 2003. Produktivitas Kerja Pengertian dan Ruang Lingkupnya. Jakarta: Prisma Sugiyono. 2006. Statistika Untuk Penelitian.Bandung: ALFABETA.

Sugiyono, 2007, Metode Kuantitatif, Kualitatif dan $R \&$ D , Cetakan Ketiga. Bandung: penerbit ALFABETA.

Sugiyono, 2010, Metode Penelitian Bisnis, Bandung: penerbit ALFABETA.

Sunyoto, Danang. 2015. Manajemen dan Pengembangan Sumber Daya Manusia (Cetakan Pertama). Yogyakarta: CAPS (Center for Academic Publishing Service)

Sedamaryanti, 2001. Sumber Daya Manusia dan Produktifitas Kerja. Bandung. Mandar Maju. Umar, Husein. 2008. Desain Penelitian MSDM dan Perilaku Karyawan. Jakarta: Penerbit PT Raja Grafindo Persada.

Wibowo, 2010. Manajemen Kinerja. Jakarta: Rajawali Press. 